\title{
Creating High-Performance Organizations in Asia: Issues to Consider
}

\author{
André de Waal \\ HPO Center, The Netherlands
}

\begin{abstract}
In recent decades the Asian continent has gained in economic importance. This advancement has not been without its problems. Therefore, in order to stay competitive, Asian companies need to transform themselves into high-performance organizations (HPO). This means that they need to know the factors that will make them world-class. This paper described the application of the HPO Framework, a holistic and scientifically validated framework for creating HPOs which has earlier been used successfully at several Asian companies where it was used to identify main organizational areas which have to be strengthened in order for these organizations to become HPOs. In this paper we investigate, based on data collected at organizations in multiple Asian countries, what the main issues are for Asian organizations which they need to address in order to become truly high performing.
\end{abstract}

Keywords: Asia; High Performance Organizations; HPO; Organizational Improvement

Received: 3 May 2020

ISSN 2056-757X
https://doi.org/10.18646/2056.72.20-007
()

Revised: 17 May 2020

Accepted: 4 June 2020 


\section{Introduction}

The Asian continent has gained much in economic importance during the past decades (Ajami, 2018; Price, 2011; Song and Tan, 2011). Spearheaded by countries like China and India (Albrecht, 2005), and supported by countries like Vietnam, the Philippines and Thailand, the continent has gained an increasingly larger share of the world economic pie, which unfortunately has not happened without problems. The main one of which seems to be the less than flawless reputation that Asian products have in many parts of the world. According to several authors, this could be caused by the low service orientation and quality of human resource management in Asian organizations (Boxall, 2012; Chan et al. 2004; Chen et al., 2016; Choi, 2014; Sumardi and Adji, 2018). In addition, just as in the rest of the world, organizations in Asia struggle with increasing pressures from the growing skilled labor shortages, higher hourly wages and calls for better environmental and labor standards (Rowley and Warner, 2013). Thus, in order to stay competitive, Asian organizations need to work at their quality by transforming themselves into highperformance organizations (HPO). An HPO is defined as "an organization that achieves financial and non-financial results that are exceedingly better than those of its peer group over a period of five years or more, by focusing in a disciplined way on that what really matters to the organization" (de Waal, 2012, p.5).

There are many models and frameworks that claim they contain the factors that make an organization perform better. But many of these have not been tested over time in longitudinal studies to evaluate whether they indeed increase organizational performance in a sustainable way. Additionally, they are not holistic in nature and typically focus only on a limited area in the organization thus making them less effective. And many of them have not been tested and evaluated in the Asian context. For our research we will use de Waal's HPO Framework (de Waal, 2012), a holistic and scientifically validated framework for creating HPOs (Do and Mai, 2020). This framework has been repeatedly tested over time (e.g. de Waal et al., 2009; de Waal and Tan Akaraborworn, 2013), has a causal relation with increased organizational performance (de Waal and Goedegebuure, 2017), and has been applied several times at Asian organizations (de Waal and Frijns, 2011; de Waal and de Haas, 2018; de Waal and Wang, 2017). Our research aim was to use the data that was collected from organizations in Asian countries, using de Waal's HPO Framework, to identify the main organizational areas which have to be strengthened in order for 'the typical Asian organization' to be able to transform into an HPO. We realize there is no such thing as 'a typical Asian organization' but it is possible to group organizations according to their regional location into a more or less homogeneous group for research purposes, as researchers have done before us (for instance Ghosh et al., 2016; Hofstede, 1980; Kloudova and Stehlikova, 2010).

Our approach was to first conduct a literature review on factors leading to high performance in the Asian context, followed by an in-depth analysis of the data collected in the past fifteen years through the means of de Waal's HPO Framework. The results of this analysis have subsequently been discussed with the participants of two conferences conducted in Singapore (SAPPHIRE Masterclass 2018 and the International Conference on Modern Tendency in Social Science 2018, with participants originating from all over Asia), to obtain further explanations for and in-depth insights in the analysis results. Our study fills a gap in the extant literature because it shows for the first time, to the best of our

International Journal of Management and Applied Research, 2020, Vol. 7, No. 2 
knowledge, how a holistic high performance excellence framework can be used in multiple Asian countries, and thus provides specific information about the factors of high performance which are of importance in the Asian context. The practical contribution of our research is that it shows the issues which in general need to be addressed by Asian organizations if and when they want to transform into HPOs.

The remainder of this article is structured as follows. In the next section, an overview of high performance studies conducted in Asia is given. This is followed by descriptions of the HPO framework and its application in Asia, and the HPO Diagnosis. Subsequently, data of Asian organizations, collected over the past fifteen years by the author, is analyzed to identify a) the current HPO-level in various Asian countries, and b) the strengths and especially the areas to improve in Asian organizations in order for them to become highperforming. The article ends with the conclusion, limitations of the research, and further opportunities for study.

\section{Research on High Performance in Asia}

Our literature search concentrated on integrated improvement methods and models used and evaluated in Asian countries. This was because improvement approaches that focus on improving one item (such as a process, system or human behavior) in general only have a limited and often short-lived impact on organizational performance. After all, most processes, systems and behaviors are intertwined and have a big reciprocal influence; therefore they cannot be considered separately (Drucker, 1964; Snee, 2009; Stålberg and Fundin, 2016). In contrast, integrated improvement approaches view an organization as a system of which all aspects have to be considered and enhanced in conjunction.

High-performance work systems (HPWS) can be considered one such integrated improvement approach, as HPWS refers to a set of coherent human resource management practices that an organization can implement with the purpose to achieve better performance (Chiang et al., 2014). A significant amount of research has been done on the effects of HPWS in Asian organizations. For instance, Chan et al. (2004) tested the direct and interactive effects of HPWS practices and organizational culture on Hong Kong firms' performance, and found that although the HPWS practices were not an important influence on performance, organizational culture was a valuable resource for companies to improve. This study was one of a minority as most studies on HPWs found positive effects. Bae et al. (2003) examined the impact of HPWS practices on organizational performance in China, India, and Vietnam, and found that HPWS techniques worked effectively in organizations in these countries. Similarly, Seong (2011) examined the relationships between HPWS, entrepreneurship and organizational culture and organizational performance in Korean small and medium-sized firms, and found significantly effects. Choi (2014) looked at the effects of several specific aspects of HPWS in South Korean firms, and found evidence of positive effects on financial performance and job satisfaction of employees. Chen et al. (2016) looked at the effects of implementing HPWS practices on employee behaviors in and organizational performance of manufacturing and service companies in Taiwan, and found significant positive correlations. Fareed et al. (2016) examined the correlation between HPWS, organizational culture, human capital development and sustainable competitive advantage in Pakistan organizations, and found positive evidence of an association. Fu et al. (2016), during a comparison of the

International Journal of Management and Applied Research, 2020, Vol. 7, No. 2 
application of HPWS in Chinese and Irish professional service firms, found a positive relationship between HPWS and organizational performance in both the Chinese and Irish firms. Finally, Muduli et al. (2016) examined the relevance of HPWS for Indian organizations and showed that HPWS aligned with employee engagement significantly improved organizational performance. It can be concluded that the majority of the studies on HPWS found positive effects of using this type of system on aspects of organizational performance.

Another integrated improvement technique, which has received much attention of researchers focusing on Asia, is the use of business excellence (BE) models, such as total quality management (TQM), the Baldrige Criteria for Performance Excellence (BCPE), and the Singapore Quality Award Criteria (SQAC). These models can be seen as a set of practices aimed at increasing the quality of the organization's processes thereby increasing its performance (Hoang et al., 2010). Several researchers looked at the effects of applying these techniques on organizational performance. For instance, Jayamaha et al. (2009) looked at the validity of three BE models used in the Asia Pacific Region (Australian Business Excellence Framework, BCPE, SQAC), and found that in general the precision of the measurement items of these models ought to be improved in order for them to be useful operationally. In contrast, Hoang et al. (2010) studies the relationship between implementing TQM and organizational characteristics in Vietnamese manufacturing and service companies, and found a positive relation with the level of innovativeness of the organization, and as a derivative performance. Mann et al. (2011) investigated the level of awareness and use of BE models in India, Japan, China, Singapore and Thailand, and found that organizations that had implemented BE models had found it to be beneficial. Tickle et al. (2016) investigated the implementation of BE models in China, India, Japan, Singapore and Thailand, and found that on average organizations with higher BE maturity outperformed their less mature counterparts. Again, the majority of researchers found positive effects of using these improvement techniques on aspects of organizational performance, albeit less evincive as in the case of HPWS research.

When looking closer at the improvement methods discussed, it is noticeable that they are admittedly integrated but not holistic per se. These methods still basically focus on one organizational area, albeit taking a grander view of that area than improvement methods focusing on a single technique or process (such as improving specific processes or systems) do. HPWS focuses on the human aspect of organizations and human resource processes, while TQM looks mostly at operational processes. A real holistic view of the organization, considering all possible relevant resources, processes, systems, and stakeholders is still missing (Berman et al., 2013). Such an approach is needed as it includes an exhaustive coverage of the research topic in question by looking at that topic from various angles and into multiple components. A holistic approach looks at a research topic from both the resource and the activity perspectives (Philpott et al., 2004). And by integrating these angles, components and perspectives, the holistic approach provides a better understanding of the research topic and its accompanying variables (Hardi and Buti, 2012). An improvement technique which can offer this desired holist approach is de Waal's HPO Framework. This framework looked at multiple disciplines and consists of a set of academically validated factors and characteristics that have a positive correlation with organizational performance (de Waal, 2012, de Waal and de Haas, 2018). In the next section the HPO Framework is described.

International Journal of Management and Applied Research, 2020, Vol. 7, No. 2 


\section{De Waal's HPO Framework}

The reason for using the HPO Framework as the analysis tool in our research is that, according to Do and Mai (2020, p. 305), "across the HPO literature, we found only the HPO framework developed by de Waal (2012) as an example of scientifically validated conceptualization of HPO". The objective of developing the HPO Framework was to identify in a holistic manner the factors that affect the sustainable high performance of an organization and to incorporate these in a framework, which could be used by organizations in an easy way to evaluate and improve themselves. The research was conducted in two phases (de Waal, 2007). The first phase constituted a literature review on high performance studies. In this review 189 characteristics potentially important for creating an HPO were identified. For each characteristic the "weighted importance" was calculated, which basically meant that the more times a characteristic occurred in the literature sources, the more "weight" the characteristic had. The characteristics with the highest "weight" were chosen as potential HPO characteristics, which gave a total of 54 characteristics.

In Phase 2, these potential HPO characteristics were included in a questionnaire that was distributed to organizations worldwide. The respondents were asked to indicate how well the unit of the organization they worked in performed on each of the 54 characteristics - on a scale from 1 (poorly) to 10 (excellent) - and also how their organizational performance compared to that of its peer group. The questionnaire yielded 2,015 responses from 1,470 organizations. With a statistical analysis, 35 characteristics which had a significant and positive correlation with organizational performance were identified and categorized into five HPO factors. These factors are:

\section{Management Quality}

HPO managers maintain trust relationships with their employees, by showing appreciation for their loyalty, treating them with attention and respect, and developing and sustaining a good relationship with them. They encourage employees to have faith and trust in themselves and others, and they treat them in a fair and honest manner. They have integrity and are a role model for employees and colleague managers. They are decisive, avoid "paralysis by analysis", and propose quick and effective actions while stimulating others to also take action. HPO managers coach and facilitate employees in such a way that these can achieve better performance. At the same time, they hold their employees responsible for their results and take corrective action when they do not perform well. They put their focus on achieving results, underline to employees the responsibility for their own performance, and are not afraid to take the difficult decisions (such as firing a person). They have an effective, self-assured and strong management style.

\section{Openness and Action Orientation}

An HPO has an open culture, which means that there is a lot of dialogue between managers and employees and among employees themselves, to exchange knowledge and experiences, and increase commitment to the organization. Managers explicitly ask for the opinions and ideas of their employees and act on that information. There is a lot of mutual respect and everybody is asked to get involved in the important affairs of the organization. There is room for experimentation and failure in the organization and there is no fear of taking (calculated) risks and making mistakes (as long as these are not repeated mistakes): these are seen as opportunities for learning. People give each other honest and sincere

International Journal of Management and Applied Research, 2020, Vol. 7, No. 2 
feedback with the goal to make things better. The HPO culture is action-driven. They take enough time for adequate decision-making but then turn their decisions quickly into actions to solve problems immediately.

\section{Long-Term Orientation}

For an HPO long-term survival and contribution to stakeholders is more important than short-term successes for shareholders. The organization and its people are extremely client-oriented: they listen carefully to what clients want and need, they understand the values and interests of clients, build excellent long-term relationships with them and have regularly direct contact with them. The organization trains and grooms its people in such a way that new management can be promoted from within. Most managers have worked for a long time in the organization, albeit in different positions and possibly different locations, and thus know the organization, its stakeholders, its products and services, its employees and its industry very well. HPOs are also a secure workplace, both in the physical as the psychological way.

\section{Continuous Improvement and Renewal}

HPOs have a strategy that is unique, either in content ("what the organization wants to achieve") or in execution ("how the organization does things") or (ideally) in both. This means that it is very clear for (potential) clients why they should go to this organization and not to other comparable organizations in the sector. An HPO improves, simplifies and aligns the processes in the organization so it can act quickly and effectively on changing circumstances. The organization tracks the information that really matters, by using critical success factors and key performance indicators. Issues are reported immediately to both managers and employees so they can deal with these quickly, and improve the way the organization is working. An HPO continuously improves and renews its products, processes and services, and strengthens its core competencies.

\section{Employee Quality}

An HPO has a diverse and complementary workforce. New people are hired that both already have HPO traits and different skills from the current workforce so that continuously new competencies are added to the organization's skill base. People are continuously developed, through formal and informal training, on-the-job training, and coaching. In this kind of environment employees want, supported by their managers, to achieve extraordinary results for which they want to be held accountable and receive feedback on.

HPO research shows that there is a direct and positive causal relationship between the five HPO factors and competitive performance: the higher the scores on the HPO factors (HPO scores), the better the results of the organization and the lower the HPO scores, the lower the competitive performance (de Waal and Goedegebuure, 2017).

According to Tickle et al. (2016), there has been much research and many case studies showing that self-assessment against an improvement model is used to identify areas for improvement. Such a self-assessment takes place during the HPO Diagnosis. This diagnosis entails an organization having its management and employees fill in the HPO questionnaire with which they evaluate their organization on whether it has achieved the 35 HPO characteristics, with possible answers on a scale of 1 (not at all) to 10 (completely). On the basis of the individual scores, the average HPO scores are calculated,

International Journal of Management and Applied Research, 2020, Vol. 7, No. 2 
visualized in a graph, and analyzed. The analysis shows whether the organization is an HPO or not; to be an HPO the average HPO score of each HPO factor has to be at least 8.5 (de Waal, 2012). The analysis also indicates which characteristics need to be improved by the organization in order to become an HPO.

\section{Use of the HPO Framework in Asia}

The HPO Framework has been used in multiple research studies done in Asian countries. In this paragraph a summarized overview is given of these studies. The HPO questionnaire was sent to employees of 26 banks in Ho Chi Minh City and Hanoi, Vietnam, and on the basis of the responses average HPO scores were calculated for each bank. Also the financial results were collected of these banks, resulting in a financial ranking from best to worst performing bank. A multiple regression was performed which showed that competitive performance was a linear function of the HPO factors (de Waal et al., 2009). In a time span of two years Nabil Bank Limited, the first Nepalese foreign joint venture bank, conducted two HPO diagnoses. In these diagnoses the financial results of Nabil Bank were compared with those of other Nepalese banks. According to this comparison, Nabil Bank was the best bank in the peer group for both Return On Assets and nonperforming loans (de Waal and Frijns, 2011). The HPO Framework was applied twice at $\mathrm{NEH}$, a Philippine banana producer and exporter. During the first diagnosis the areas to improve were identified. The second HPO Diagnosis showed that both NEH's HPO scores and organizational results had gone up considerably, such as a large increase in production and sales turnover (de Waal and de Haas, 2018).

The HPO questionnaire was distributed to employees of a Chinese state-owned manufacturing enterprise. The resulting scores were discussed during a workshop to arrive at the main attention points for the organization. The participants concluded during this workshop that the HPO framework was valid and useful for the Chinese context and yielded valuable recommendations for improvement of the company (de Waal and Wang, 2017). In the final research study described here, during two workshops and seminars in Bangkok, Thailand, participants were asked to complete the HPO questionnaire. The collected data were analyzed using a confirmatory factor analysis and the data yielded, with a high reliability, four of the five HPO factors as present in the original HPO framework. The dropped items were either confounded with other factors or items that may be another dimension in the data or a sub-dimension of other factors. As such, the HPO framework proved to be valid and useful for Thai organizations to improve themselves (de Waal and Akaraborworn, 2013; de Waal et al., 2014).

\section{Research Approach and Results}

Since the HPO diagnosis has been introduced in 2007, more than 55000 respondents have filled-in the HPO questionnaire, and the scores have been collected in the HPO database. From this database we extracted the data from in total 1342 respondents who had indicated they worked for an Asian organization. We averaged the scores these respondents gave to arrive at an overall average HPO score for Asian organizations (see Figure 1). In Appendix the detailed average scores are given per HPO characteristic, for the Asian organizations in the HPO database.

International Journal of Management and Applied Research, 2020, Vol. 7, No. 2 
Figure 1: Average HPO scores for Asian organizations

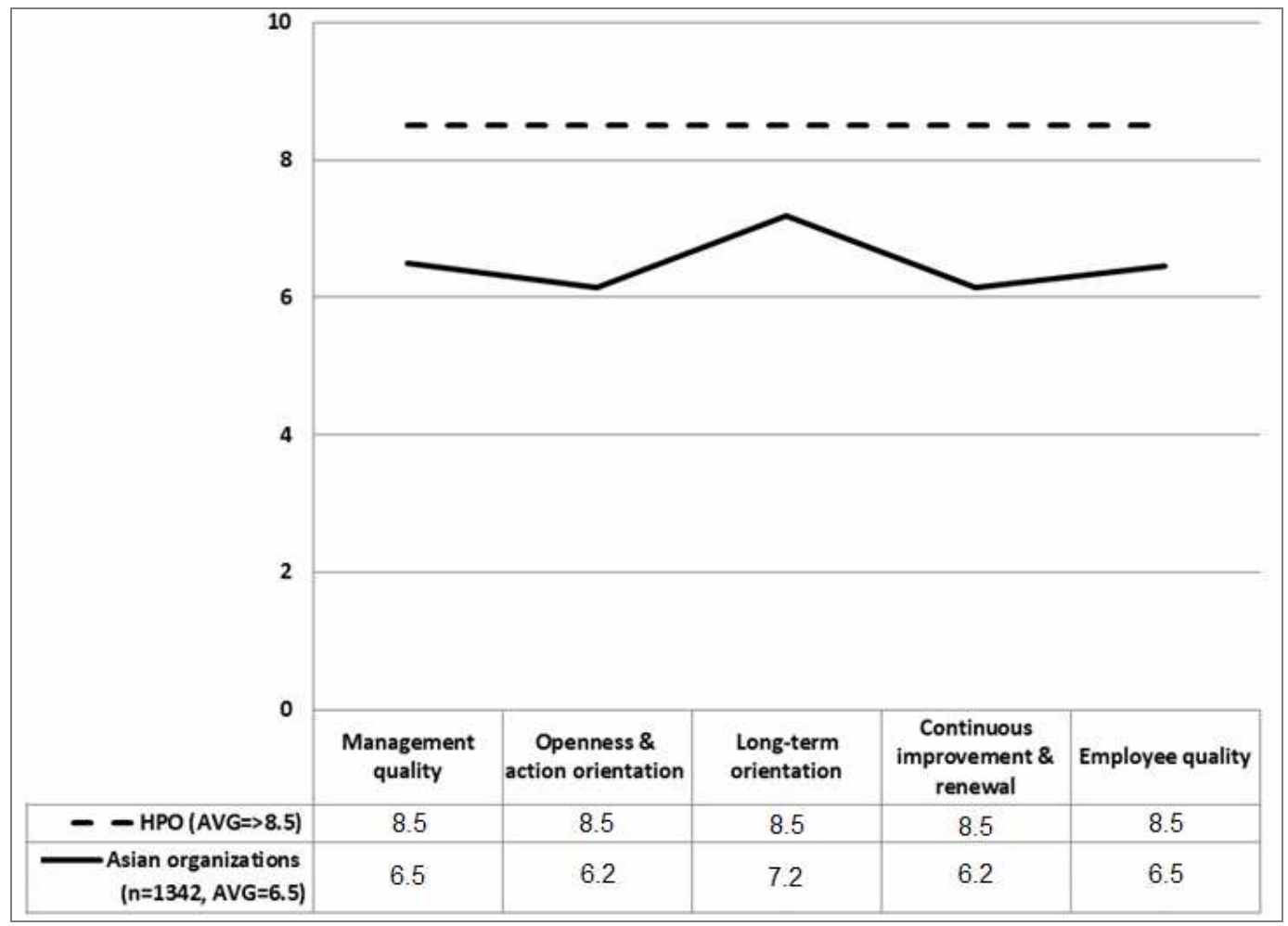

Figure 1 shows that on average organizations in Asia are not high-performing yet, as the HPO-level starts at 8.5 (de Waal, 2012). At the same time the Asian organizations have a rather balanced profile: except for HPO factor Long-term orientation, all the factors score in the 6.2-6.5 range. HPO factor Long-term orientation scores higher (7.2), an indication of a relative strong orientation on the long-term that characterizes Asian culture (Buck et al., 2010; Hofstede and Minkov, 2010; Ryu and Moon, 2009). As mentioned before, these HPO scores were discussed with the participants of two conferences conducted in Singapore in 2018. These participants remarked that there exists a high loyalty among people in Asia because of their in general strong family upbringing, which translates to loyalty in the workplace, strengthening the long-term orientation of organizations (Abdul and Ibrahim, 2002; Lupu et al., 2018; Wong and Slater, 2002).

Looking at HPO factors Continuous Improvement \& Renewal and Openness \& Actionorientation, the conference participants remarked that Asians in general seem to typically be followers, not innovators, which make it difficult to be frontrunners in continuous improvement and renewal (Berman et al., 2013; Licuanan et al., 2015). The participants also wondered how open to influences of other cultures and management techniques, which often are sources of new insights, Asian organizations are. In addition, the follower attitude prevents employees of going into discussion and dialogue with their managers, something which is reinforced by the typical top-down management style still applied in many Asian organizations where a great power distance exist (Berman et al., 2013; Chen et al., 2017; Hofstede, 1981).

International Journal of Management and Applied Research, 2020, Vol. 7, No. 2 
HPO factors Management Quality and Employee Quality score average which can be explained by the fact that the field of HRM is still evolving in the region, causing a comparative lack of attention for the specific development of people skills which still exist in many Asian organizations, although in recent years modern HRM practices have gained more acceptance (Budhwar and Debrah, 2009; Rowley and Benson, 2002; Zanko, 2003). Figure 1 thus supports the contention made in the Introduction that there is an urgent need for Asian organizations to become high-performing, as there is a 2-point gap with the high-performance level. This contention is supported by Mann et al. (2011, p. 604) who state that the Asian region "still suffers from some barriers to long-term commitment to business excellence including lack of development of a business excellence culture, a lack of resources and a failure to fully educate the majority of staff in business excellence." Their view is mirrored by Budhwar and Debrah (2009, p. 214): "In this globalized era, competitive pressures have laid bare the limitations of the traditional models of management in some Asian countries."

Subsequently, we broke down the data of the 1443 respondents into average HPO scores per country, with the threshold of at least 30 respondents (see Figure 2). One has to be careful with interpreting Figure 2 as for several countries there was only a limited number of respondents available; the discussion on the data can therefore only be indicative. All the same, distinct differences in HPO scores can be noticed between the various Asian countries, with China, India, Philippines, Singapore and Taiwan having higher scores than the average, while especially Nepal seems to be lagging. These differences between countries have also been found in previous research.

Figure 2: Average HPO scores per Asian country



Deshpandé et al. (2004) noted that, in their comparison of business-to-business firms based in China, Hong Kong, India, Japan, Thailand, and Vietnam, differences across countries can be found on organizational dimensions such as innovativeness, market orientation, and organizational climate and culture, and that in general these differences were consistent with the countries' historical and cultural differences. This finding is mirrored by Rabl et al. (2014) who noted in their research of the effects of HPWS

International Journal of Management and Applied Research, 2020, Vol. 7, No. 2 
significant differences between countries, among which China, Hong Kong, India, Japan, Singapore, South Korea and Taiwan. Tickle et al. (2016) stated that India, Japan, China, Singapore, and Thailand had the most advanced BE organizations which would translate in our research into countries having the highest HPO scores. In the case of China and Singapore this is indeed confirmed by Figure 2. It also has to be noted that most Philippines' data came from one company which was transforming itself to an HPO (de Waal and de Haas, 2018) which in general gives a bias toward a higher score (de Waal, 2012) and thus the average HPO score for the Philippines might not be representative.

While discussing the results of Figure 2 during the two conference in Singapore, several reasons for the differences between countries were suggested by the participants, most of which are supported by previous research:

- Degree of economic and social development. If a country's economy is in an early development stage, the systems in that country (such as law and regulations) are not as developed thus not supporting businesses adequately (Rowley and Warner, 2007). Organizations making up this economy thus have trouble to develop themselves and therefore will have a comparative lower level. Examples are Bhutan, Indonesia and Nepal.

- Transfer of non-Asian management techniques. Rowley and Warner (2007, p. 389) for instance observe "We find a strong foreign influence, in particular from the US (as well as from Japan), on how people management systems in Asia have developed. The more dependent on foreign capital and MNCs' activities countries are (for example, Taiwan, Malaysia, Thailand), the more Western style HRM practices may be adopted." These techniques, although not all of them transferable in indiscriminately form the Western to the Asian context, will help Asian organizations to at least reflect on their own management model (Fu et al., 2016) and entice them to improve these, resulting in higher HPO scores.

- Education level. If there is a low level of attention to education, especially management development, there will be less attention for learning and subsequently applying new management techniques, resulting in lower HPO scores (Wong and Slater, 2002). In contrast, if the Government is strongly in favor of education and organization supports life-long learning, quality of management and employees will increase (Fu et al., 2016; Khan and Afzal, 2011; Sumardi and Adji, 2018), resulting in higher HPO scores. Example is Singapore.

- Effect of competition. The more competitive a country's industries are (both locally and internationally), the better organizations in those industries have to be. They will therefore pay dedicated attention to making their organizations stronger, resulting in higher HPO scores (Lin and Wu, 2013; Ting, 2015; Uddin and Suzuki, 2014). Examples are China and Singapore.

- Effect of corruption. The more corrupt a country is, the less possibilities (i.e. resources) there will be remaining for developing the organization (Blagojević and Damijan, 2013; Habiyaremye and Raymond, 2018; Wu, 2002), resulting in lower HPO scores.

International Journal of Management and Applied Research, 2020, Vol. 7, No. 2 
- Consequences of natural disasters. If a country regularly experiences natural disasters, most attention, efforts and resources need to go to dealing with their consequences. As a result, there will not be much left for organizational development, resulting in lower HPO scores (Duncan et al., 2011; Sadiq and Graham, 2016). Examples are Indonesia and Nepal.

\section{Possible Improvements for Strengthening Asian Organizations}

The HPO Framework indicates what is important for an organization to improve (de Waal, 2012). The next step for organizations is to take steps to strengthen the organization by addressing the attention points originating from the HPO Diagnosis (Boxall, 2012). Therefore, in this section the main attention points to be addressed by Asian organizations are discussed. This is a general overview of attention points as this article discusses the general state of Asian organizations. When starting to improve there will be of course differences in countries and between organizations (Rowley and Ulrich, 2012). There are three main improvement points and the participants of the two Singapore conferences suggested that Asian organizations need to address specific questions for each improvement point:

1. Improve the process of process improvement (HPO factor Continuous Improvement and Renewal). When addressing this attention point, organizations have to contemplate the following questions: Do we start too many projects?, Do we know when a project is finished?, Do we have enough information and discipline to improve successfully? And do we know what's happening in the organization?

2. Use all the intellect in the organization (HPO factor Openness and Action-Orientation). When addressing this attention point, organizations have to contemplate the following questions: Are we communicating instead of dialoguing? Do we 'profit' enough of the collective knowledge in the company? And do we cooperate enough in the company?

3. Create high-performing managers (HPO factor Management Quality). When addressing this attention point, organizations have to contemplate the following questions: Do we possess the qualities to become 'High Performance Managerial Leaders' (de Waal, 2020)? Are we decisive and effective enough? And do we spend enough time developing the next generation of managers?

\section{Conclusion}

In this paper we aimed to use de Waal's HPO framework (Waal, 2012) to identify the main organizational areas which must be strengthened in order for Asian organizations to be able to transform into HPOs. We used this framework as we wanted to employ a holistic improvement technique which considers all matters possibly of importance for the performance of Asian organizations. Based on previous research which used de Waal's HPO Framework we showed that it was justified to apply this framework, not only because it was shown to be valid for the Asian context but also because Asian organizations in those research studies in general achieve better organizational performance. Based on the data collected on Asian organizations in the past fifteen years, employing the HPO Questionnaire, we were able to calculate the overall HPO score for

International Journal of Management and Applied Research, 2020, Vol. 7, No. 2 
Asian organizations and also for several Asian countries. In addition, we identified the three main attention points Asian organizations need to address in order to be able to transform themselves into HPOs. Our study thus contributes to the research of Asian organizations as it provides other scholars with a holistic framework which can used in future studies. Our study also has practical implications as Asian organizations not only now have at their disposal a validated holistic analysis and improvement method but also already know three areas for future improvement.

Our research has several limitations. The most obvious one is the limited number of responses for the countries. Future research should concentrate on getting much more data, so that not only an analysis can be made on country level but also on for instance industry and sector level inside the country. Another limitation is that several Asian countries were not included in our study. Future research should aim at getting data form additional countries so a better coverage of the Asian continent is achieved. A third limitation is that we have not investigated whether addressing the three attention points increases the HPO scores and organizational performance. Future research, probably in the shape of case studies, should look into the correlation between attention points, HPO scores and organizational performance, while at the same time trying to uncover the underlying mechanisms which (potentially) lead to organizational improvement.

Acknowledgement: the author thanks the participants of the SAPPHIRE Masterclass (Singapore, April 2018) and the International Conference on Modern Tendency in Social Science 2018 (Singapore, April 2018) for their insightful comments.

\section{References}

1. Abdul, Z. and Ibrahim, S. (2002), "Executive and management attitudes towards corporate social responsibility in Malaysia", Corporate Governance, Vol. 2 No. 4, pp. 10-16. https://doi.org/10.1108/14720700210447641

2. Ajami, R. A. (2018), "The Tale of Three Cities - Da Nang, Nanjing, and Washington: Titanic Economic Shifts Across Asia-Pacific Economies", Journal of Asia-Pacific Business, Vol. 19, No. 1, pp. 1-3. https://doi.org/10.1080/10599231.2018.1419041

3. Albrecht, T. (2005), "Where is the 'Economic Centre' of the Asia Pacific Region?", Journal of the Asia Pacific Economy, Vol. 10, No. 3, pp. 359-379. https://doi.org/10.1080/13547860500163522

4. Bae, J., Chen, S., David, W., Tai, W, Lawler, J.J. and Walumbwa, F.O. (2003), "Human resource strategy and firm performance in Pacific Rim countries", International Journal of Human Resource Management, Vol. 14, No. 8, pp. 1308-1332. https://doi.org/10.1080/0958519032000145774

5. Berman, E., Sabharwal, M., Wang, C.Y., West, J., Jing, Y., Jan, C.Y., Liu, W., Brillantes, A., Chen, C.A. and Gomes, R. (2013), "The Impact of Societal Culture on the Use of Performance Strategies in East Asia: Evidence from a comparative survey", Public Management Review, Vol. 15, No. 8, pp. 1065-1089. https://doi.org/10.1080/14719037.2013.816522

6. Blagojević, S, and Damijan, J. P. (2013), "The impact of corruption and ownership on the performance of firms in Central and Eastern Europe", Post-Communist Economies, Vol. 25, No. 2, pp. 133-158. https://doi.org/10.1080/14631377.2013.787734

International Journal of Management and Applied Research, 2020, Vol. 7, No. 2 
7. Boxall. P. (2012), "High-performance work systems: what, why, how and for whom?", Asia Pacific Journal of Human Resources, Vol. 50, No. 2, pp. 169-186. https://doi.org/10.1111/j.1744-7941.2011.00012.x

8. Buck, T., Liu, X. and Ott, U. (2010), "Long-term orientation and international joint venture strategies in modern China", International Business Review, Vol. 19, No. 3, pp. 223-234. https://doi.org/10.1016/j.ibusrev.2009.12.005

9. Budhwar, P. and Debrah, Y. (2009), "Future research on human resource management systems in Asia", Asia Pacific Journal of Management, Vol. 26, No. 2, pp. 197-218. https://doi/10.1007/s10490-008-9103-6

10. Chan, L.L.M., Shaffer, M.A. and Snape, E. (2004), "In search of sustained competitive advantage: the impact of organizational culture, competitive strategy and human resource management practices on firm performance", International Journal of Human Resource Management, Vol. 15, No. 1, pp. 17-35. https://doi.org/10.1080/0958519032000157320

11. Chen, T., Li, F. and Leung, K. (2017), "Whipping into shape: Construct definition, measurement, and validation of directive-achieving leadership in Chinese culture", Asia Pacific Journal of Management, Vol. 34, No. 3, pp. 537-563. https://doi.org/10.1007/s10490-0179511-6

12. Chen, S.Y., Uen, J. and Chen, C. C. (2016), "Implementing high performance HR practices in Asia: HR practice consistency, employee roles, and performance", Asia Pacific Journal of Management, Vol. 33, No. 4, pp. 937-958. https://doi.org/10.1007/s10490-016-9466-z

13. Chiang, Y.H., Hsu, C.C. and Shih, H.A. (2015), "Experienced high performance work system, extroversion personality, and creativity performance", Asia Pacific Journal of Management, Vol. 32, No. 2, pp. 531-549. https://doi.org/10.1007/s10490-017-9511-6

14. Choi, J. H. (2014), "The HR-performance link using two differently measured HR practices", Asia Pacific Journal of Human Resources, Vol. 52, No. 3, pp. 370-387. https://doi.org/10.1111/1744-7941.12009

15. Deshpandé, R., Farley, J.U. and Bowman, D. (2004), "Tigers, dragons and others: profiling high performance in Asian firms", Journal of International Marketing, Vol. 12, No. 3, pp. 529. https://doi.org/10.1509\%2Fjimk.12.3.5.38101

16. de Waal A. A. (2007), "The characteristics of a high performance organization", Business Strategy Series, Vol. 8 No. 3, pp. 179-185. https://doi.org/10.1108/17515630710684178

17. de Waal, A. A. (2012), What Makes a High Performance Organization: Five Validated Factors of Competitive Performance that Apply Worldwide, Enfield: Global Professional Publishing.

18. de Waal, A. A. (2020),High Performance Managerial Leadership: Best Ideas From Around The World, Santa Barbara: Prager.

19. de Waal, A. and de Haas, J. (2018), "Longitudinal research into the effects of the high performance organisation framework: the case of NEH the Philippines", International Journal of Productivity and Performance Management, Vol. 67, No. 65, pp. 985-999. https://doi.org/10.1108/IJPPM-08-2017-0183

20. de Waal, A.; Duong, H. and Ton, V. (2009), "High performance in Vietnam: the case of the Vietnamese Banking Industry", Journal of Transnational Management, Vol. 14, No. 3, pp. 179-201. https://doi.org/10.1080/15475770903120196

International Journal of Management and Applied Research, 2020, Vol. 7, No. 2 
21. de Waal, A.A. and Frijns, M. (2011), "Longitudinal research into factors of high performance: the follow-up case of Nabil Bank", Measuring Business Excellence, Vol. 15 No. 1, pp. 4-19. https://doi.org/10.1177\%2F2158244017736801

22. de Waal, A. A. and Goedegebuure, R. (2017), "Investigating the causal link between a management improvement technique and organizational performance: The case of the HPO framework", Management Research Review, Vol. 40, No. 4, pp. 429-450. https://doi.org/10.1108/MRR-03-2016-0058

23. de Waal, A.; Goedegebuure, R. and Akaraborworn, C.T. (2014), "Adapting the high performance organization framework to the Thai context", Measuring Business Excellence, Vol. 18 No. 2, pp. 28-38. https://doi.org/10.1108/MBE-08-2013-0043

24. de Waal, A. and Tan Akaraborworn, C. (2013), "Is the high performance organization framework suitable for Thai organizations?", Measuring Business Excellence, Vol. 17 No. 4, pp. 76-87. https://doi.org/10.1108/MBE-01-2013-0001

25. de Waal, A. and Wang, A. (2017), "Applicability of the high performance organization (HPO) framework in the Chinese context: The case of a state-owned enterprise", Journal of Chinese Human Resource Management, Vol. 8 No. 1, pp. 22-39. https://doi.org/10.1108/JCHRM-062016-0007

26. Do, T. and Mai, N. (2020), "High-performance organization: a literature review", Journal of Strategy and Management, Vol. 13, No. 2, pp. 297-309. https://doi.org/10.1108/JSMA-112019-0198

27. Drucker, P. (1964), Managing for Results: Economic Tasks and Risk-Taking Decisions, New York: Harper-Collins.

28. Duncan, W. J., Yeager, V.A., Rucks, A.C. and Ginter, P.M. (2011), "Surviving organizational disasters", Business Horizons, Vol. 54, No. 2, pp. 135-142. https://doi.org/10.1016/j.bushor.2010.10.005

29. Fareed, M., Noor, W.S.W.M., Isa, M.F.M. and Salleh, S.S.M.M. (2016), "Developing Human Capital for Sustainable Competitive Advantage: The Roles of Organizational Culture and High Performance Work System", International Journal of Economic Perspectives, Vol. 10, No. 4 , pp. 655-673.

30. Fu, N., Ma, Q., Flood, P.C, Bosak, J., Liu, Y. and Zhang, Y. (2016), "When East meets West: comparing the utilization of high-performance work systems in Chinese and Irish professional service firms", Asia Pacific Journal of Human Resources, Vol. 54, No. 1, pp. 8-31. https://doi.org/10.1111/1744-7941.12094

31. Ghosh, A., Ranganathan, R. and Rosenkopf, L. (2016), "The impact of context and model choice on the determinants of strategic alliance formation: Evidence from a staged replication study", Strategic Management Journal, Vol. 37, No. 11, pp. 2204-2221. https://doi.org/10.1002/smj.2570

32. Habiyaremye, A. and Raymond, W. (2018), "How do foreign firms' corruption practices affect innovation performance in host countries? Industry-level evidence from transition economies", Innovation: Organization \& Management, Vol. 20, No. 1, pp. 18-41. https://doi.org/10.1080/14479338.2017.1367626

International Journal of Management and Applied Research, 2020, Vol. 7, No. 2 
33. Hardi, P. and Buti, K. (2012), "Corporate governance variables: lessons from a holistic approach to Central-Eastern European practice”, Corporate Governance, Vol. 12 No. 1, pp. 101-117. https://doi.org/10.1108/14720701211191364

34. Hoang, D.T., Igel, B. and Laosirihongthong, T. (2010), "Total quality management (TQM) strategy and organisational characteristics: Evidence from a recent WTO member", Total Quality Management \& Business Excellence, Vol. 21, No. 9, pp. 931-951. https://doi.org/10.1080/14783363.2010.487680

35. Hofstede, G. (1980), Culture's Consequences: International Differences in Work-Related Values, USA: Sage Publications.

36. Hofstede, G. and Minkov, M. (2010), "Long- versus short-term orientation: new perspectives", Asia Pacific Business Review, Vol. 16, No. 4, pp. 493-504. https://doi.org/10.1080/13602381003637609

37. Jayamaha, N., Grigg, N. and Mann, R. (2009), "A study of the validity of three major business excellence models in the Asia Pacific region", Total Quality Management \& Business Excellence, Vol. 20, No. 11, pp. 1213-1227. https://doi.org/10.1080/14783360903247536

38. Khan, M.A. and Afzal, H. (2011), "High level of education builds up strong relationship between organizational culture and organization performance in Pakistan", International Journal of Human Resource Management, Vol. 22, No. 7, pp. 1387-1400. https://doi.org/10.1080/09585192.2011.561955

39. Kloudova, J. and Stehlikova, B. (2010), "Creativity index for the Czech republic in terms of regional similarities and geographic location", Economics \& Management, pp. 100-109.

40. Kramar, R. and Parry, E. (2014), "Strategic human resource management in the Asia Pacific region: similarities and differences?", Asia Pacific Journal of Human Resources, Vol. 52, No. 4, pp. 400-419. https://doi.org/10.1111/1744-7941.12042

41. Licuanan, V.S., Sengupta, K. and Neelankavil, J.P. (2015), "Entrepreneurship and innovation initiatives among Asian multinationals", International Journal of Commerce \& Management, Vol. 25, No. 1, pp. 67-83. https://doi.org/10.1108/IJCoMA-02-2013-0014

42. Lin, L. and Wu, G. (2013), "Service competition, firm performance and resource allocation in manufacturing: evidence from firm-level data in China", International Journal of Innovation \& Technology Management, Vol. 10, No. 4, pp. 1-39. https://doi.org/10.1142/S0219877013500107

43. Lupu, I., Spence, C. and Empson, L. (2018), "When the past comes back to haunt you: The enduring influence of upbringing on the work-family decisions of professional parents", Human Relations, Vol. 71, No. 2, pp. 155-181. https://doi.org/10.1177\%2F0018726717708247

44. Mann, R., Adebanjo, D., Laosirihongthong, T. and Punnakitikashem. (2011), "Awareness and impact of business excellence in Asia", Total Quality Management \& Business Excellence, Vol. 22, No. 11, pp. 1237-1258. https://doi.org/10.1080/14783363.2011.624772

45. Muduli, A.; Verma, S. and Datta, S.J.K. (2016), "High Performance Work System in India: Examining the Role of Employee Engagement", Journal of Asia-Pacific Business, Vol. 17, No. 2, pp. 130-150. https://doi.org/10.1080/10599231.2016.1166021

46. Philpott, E., Hamblin, D. J., Baines, T. and Kay, G. (2004), "The use of models and methods for strategic planning: Towards an holistic view of strategy", International Transactions in

International Journal of Management and Applied Research, 2020, Vol. 7, No. 2 
Operational Research, Vol. 11, No. 2, pp. 203-216. https://doi.org/10.1111/j.14753995.2004.00452.x

47. Price, G. (2011), Asia and Europe: Engaging for a Post-Crisis World, Asia Programme Paper ASP PP 2011/01, London: Chatham House.

48. Rabl, T., Jayasinghe, M., Gerhart, B. and Kühlmann, T.M. (2014), "A Meta-Analysis of Country Differences in the High-Performance Work System-Business Performance Relationship: The Roles of National Culture and Managerial Discretion", Journal of Applied Psychology, Vol. 99, No. 6, pp. 1011-1041. https://doi.org/10.1037/a0037712

49. Rowley, C. and Benson, J. (2002), "Convergence and Divergence in Asian Human Resource Management", California Management Review, Vol. 44, No. 2, pp. 90-109. https://doi.org/10.2307\%2F41166124

50. Rowley, C. and Ulrich, D. (2012), "Conclusion: lessons learned and insights derived from leadership in Asia", Asia Pacific Business Review, Vol. 18, No. 4, pp. 675-681. https://doi.org/10.1080/13602381.2012.694725

51. Rowley, C. and Warner, M. (2013), "Strategic challenges and issues for Chinese managers and management in the global economy: conclusions", Asia Pacific Business Review, Vol. 19, No. 4, pp. 617-624. https://doi.org/10.1080/13602381.2013.832918

52. Rubini, L. and Barbieri, E. (2013), "Guangdong province, China: firms, cities and sectors of excellence", Measuring Business Excellence, Vol. 17, No. 2, pp. 5-18. https://doi.org/10.1108/13683041311329401

53. Ryu, S. and Moon, C.W. (2009), "Long-Term Orientation As A Determinant Of Relationship Quality Between Channel Members", International Business \& Economics Research Journal<, Vol. 8, No. 11, pp. 1-9. https://doi.org/10.19030/iber.v8i11.3180

54. Sadiq, A.A. and Graham, J.D. (2016), "Exploring the Predictors of Organizational Preparedness for Natural Disasters", Risk Analysis: An International Journal, Vol. 36, No. 5, pp. 1040-1053. https://doi.org/10.1111/risa.12478

55. Seong, J.Y. (2011), "The Effects of High Performance Work Systems, Entrepreneurship and Organizational Culture on Organizational Performance", Seoul Journal of Business, Vol. 17, No. 1, pp. 3-36. https://doi.org/10.35152/snusjb.2011.17.1.001

56. Snee, R.D. (2009), "Digging the Holistic Approach: Rethinking Business Improvement to Improve the Bottom Line", Quality Progress, Vol. 42, No. 10, pp. 52-54.

57. Song, L.L. and Tan, S.L. (2011), "Business Cycle Co-movement between Australia and East Asia", Australian Economic Review, Vol. 44, No. 4, pp. 427-436. https://doi.org/10.1111/j.1467-8462.2011.00657.x

58. Stålberg, L. and Fundin, A. (2016), "Exploring a holistic perspective on production system improvement", International Journal of Quality \& Reliability Management, Vol. 33, No. 2, pp. 267-283. https://doi.org/10.1108/IJQRM-11-2013-0187

59. Seleim, A. and Bontis, N. (2009), "The relationship between culture and corruption: a cross-national study", Journal of Intellectual Capital, Vol. 10 No. 1, pp. 165-184. https://doi.org/10.1108/14691930910922978

60. Sumardi, F. and Adji, A.R. (2018), "The mediating effect of service quality and organizational commitment on the effect of management process alignment on higher education performance

International Journal of Management and Applied Research, 2020, Vol. 7, No. 2 
in Makassar, Indonesia", Journal of Organizational Change Management, Vol. 31 No. 2, pp. 410-425. https://doi.org/10.1108/JOCM-11-2016-0247

61. Tickle, M.; Mann, R. and Adebanjo, D. (2016), "Deploying business excellence - success factors for high performance", International Journal of Quality \& Reliability Management, Vol. 33 No. 2, pp. 197-230. https://doi.org/10.1108/IJQRM-10-2013-0160

62. Wong, A. and Slater, J.R. (2002), "Executive development in China: is there any in a Western sense?", International Journal of Human Resource Management, Vol. 13, No. 2, pp. 338-360. https://doi.org/10.1080/09585190110103052

63. Uddin, S.M.S. and Suzuki, Y. (2014), "The impact of competition on bank performance in Bangladesh: an empirical study", International Journal of Financial Services Management, Vol. 7, No. 1, pp. 73-94. https://doi.org/10.1504/IJFSM.2014.062293

64. Wu, C.F. (2002), "The Relationship of Ethical Decision-Making to Business Ethics and Performance in Taiwan", Journal of Business Ethics, Vol. 35, No. 3, pp. 163-176. https://doi.org/10.1023/A:1013853107403

65. Zanko, M. (2003), "Change and diversity: HRM issues and trends in the Asia-Pacific region", Asia Pacific Journal of Human Resources, Vol. 41, No. 1, pp. 75-87. https://doi.org/10.1177/1038411103041001024

\section{Appendix 1}

This Appendix lists the five HPO factors with their accompanying characteristics. It also gives the average HPO scores per characteristic, for the Asian organizations in the HPO database.

\begin{tabular}{|c|c|c|c|}
\hline HPO factors & No. & HPO characteristics & Score \\
\hline $\begin{array}{l}\text { Continuous } \\
\text { Improvement }\end{array}$ & 1 & $\begin{array}{l}\text { Our organization has adopted a strategy that sets it clearly apart } \\
\text { from other organizations. }\end{array}$ & 6.3 \\
\hline $\begin{array}{l}\text { Continuous } \\
\text { Improvement }\end{array}$ & 2 & In our organization processes are continuously improved. & 6.5 \\
\hline $\begin{array}{l}\text { Continuous } \\
\text { Improvement }\end{array}$ & 3 & In our organization processes are continuously simplified. & 5.9 \\
\hline $\begin{array}{l}\text { Continuous } \\
\text { Improvement }\end{array}$ & 4 & In our organization processes are continuously aligned. & 6.1 \\
\hline $\begin{array}{l}\text { Continuous } \\
\text { Improvement }\end{array}$ & 5 & $\begin{array}{l}\text { In our organization everything that matters to the organization's } \\
\text { performance is explicitly reported. }\end{array}$ & 6.2 \\
\hline $\begin{array}{l}\text { Continuous } \\
\text { Improvement }\end{array}$ & 6 & $\begin{array}{l}\text { In our organization both financial and non-financial information is } \\
\text { reported to organizational members. }\end{array}$ & 5.8 \\
\hline $\begin{array}{l}\text { Continuous } \\
\text { Improvement }\end{array}$ & 7 & Our organization continuously innovates its core competencies. & 6.1 \\
\hline $\begin{array}{l}\text { Continuous } \\
\text { Improvement }\end{array}$ & 8 & $\begin{array}{l}\text { Our organization continuously innovates its products, processes } \\
\text { and services. }\end{array}$ & 6.4 \\
\hline $\begin{array}{l}\text { Openness \& } \\
\text { Action Orientation }\end{array}$ & 9 & My manager frequently engages in a dialogue with employees. & 6.2 \\
\hline $\begin{array}{c}\text { Openness \& } \\
\text { Action Orientation }\end{array}$ & 10 & $\begin{array}{l}\text { Organizational members spend much time on knowledge } \\
\text { exchange and learning from each other. }\end{array}$ & 6.1 \\
\hline $\begin{array}{c}\text { Openness \& } \\
\text { Action Orientation }\end{array}$ & 11 & $\begin{array}{l}\text { Organizational members are always involved in important } \\
\text { processes. }\end{array}$ & 6.0 \\
\hline $\begin{array}{c}\text { Openness \& } \\
\text { Action Orientation }\end{array}$ & 12 & My manager allows making mistakes. & 5.5 \\
\hline Openness \& & 13 & My manager welcomes change. & 6.6 \\
\hline
\end{tabular}

International Journal of Management and Applied Research, 2020, Vol. 7, No. 2 


\begin{tabular}{|c|c|c|c|}
\hline Action Orientation & & & \\
\hline $\begin{array}{c}\text { Openness \& } \\
\text { Action Orientation }\end{array}$ & 14 & Our organization is performance driven. & 6.6 \\
\hline $\begin{array}{l}\text { Management } \\
\text { Quality }\end{array}$ & 15 & My manager is trusted by organizational members. & 6.7 \\
\hline $\begin{array}{l}\text { Management } \\
\text { Quality }\end{array}$ & 16 & My manager has integrity. & 6.9 \\
\hline $\begin{array}{l}\text { Management } \\
\text { Quality }\end{array}$ & 17 & My manager is a role model for organizational members. & 6.5 \\
\hline $\begin{array}{l}\text { Management } \\
\text { Quality }\end{array}$ & 18 & My manager applies fast decision making. & 6.3 \\
\hline $\begin{array}{l}\text { Management } \\
\text { Quality }\end{array}$ & 19 & My manager applies fast action taking. & 6.2 \\
\hline $\begin{array}{l}\text { Management } \\
\text { Quality }\end{array}$ & 20 & $\begin{array}{l}\text { My manager coaches organizational members to achieve better } \\
\text { results. }\end{array}$ & 6.4 \\
\hline $\begin{array}{c}\text { Management } \\
\text { Quality }\end{array}$ & 21 & My manager focuses on achieving results. & 7.1 \\
\hline $\begin{array}{l}\text { Management } \\
\text { Quality }\end{array}$ & 22 & My manager is very effective. & 6.4 \\
\hline $\begin{array}{l}\text { Management } \\
\text { Quality }\end{array}$ & 23 & My manager applies strong leadership. & 6.6 \\
\hline $\begin{array}{l}\text { Management } \\
\text { Quality }\end{array}$ & 24 & My manager is confident. & 6.7 \\
\hline $\begin{array}{l}\text { Management } \\
\text { Quality }\end{array}$ & 25 & My manager is decisive with regard to non-performers. & 5.6 \\
\hline $\begin{array}{l}\text { Management } \\
\text { Quality }\end{array}$ & 26 & $\begin{array}{l}\text { My manager always holds organizational members responsible for } \\
\text { their results. }\end{array}$ & 6.6 \\
\hline Employee Quality & 27 & $\begin{array}{l}\text { My manager inspires organizational members to accomplish } \\
\text { extraordinary results. }\end{array}$ & 6.3 \\
\hline Employee Quality & 28 & Organizational members are trained to be resilient and flexible. & 6.2 \\
\hline Employee Quality & 29 & Our organization has a diverse and complementary workforce. & 6.6 \\
\hline Employee Quality & 30 & $\begin{array}{l}\text { Our organization grows through partnerships with suppliers and/or } \\
\text { customers. }\end{array}$ & 6.8 \\
\hline $\begin{array}{l}\text { Long term } \\
\text { orientation }\end{array}$ & 31 & $\begin{array}{l}\text { Our organization maintains good and long-term relationships with } \\
\text { all stakeholders. }\end{array}$ & 7.2 \\
\hline $\begin{array}{l}\text { Long term } \\
\text { orientation }\end{array}$ & 32 & $\begin{array}{l}\text { Our organization is aimed at servicing the customers as best as } \\
\text { possible. }\end{array}$ & 7.8 \\
\hline $\begin{array}{l}\text { Long term } \\
\text { orientation }\end{array}$ & 33 & My manager has been with the company for a long time. & 7.1 \\
\hline $\begin{array}{l}\text { Long term } \\
\text { orientation }\end{array}$ & 34 & New management is promoted from within the organization. & 6.5 \\
\hline $\begin{array}{l}\text { Long term } \\
\text { orientation }\end{array}$ & 35 & $\begin{array}{l}\text { Our organization is a secure workplace for organizational } \\
\text { members. }\end{array}$ & 7.4 \\
\hline
\end{tabular}

International Journal of Management and Applied Research, 2020, Vol. 7, No. 2 